\title{
SOCIAL STUDIES LEARNING MODEL IN LOCAL CLASSIC BATIK CULTURAL BASED FOR THE NATION IDENTITY REINFORCEMENT OF JUNIOR HIGH SCHOOL STUDENTS
}

\begin{abstract}
Sariyatun ${ }^{1}$
ABSTRACT

The development of social studies learning model is based on classic batik local cultural value for improving the identity of Junior High School Students in Surakarta. Generally, the research is aimed to construct social study based on classic batic local cultural value to improve nation identity through using post modernism thought that views understanding a curriculum as a praxis. Based on the construction, this research is able to empower the researcher, social studies teachers and students. In order to construct the transformative curriculum as the praxis, four elements are used richness, recursions, relations and rigor. The integration of classic batik cultural value in social studies learning is based on the combination of cooperative learning model and value clarification. Knowledge and understanding to local and national cultural values will be manifested to nation identity. This research uses research and development approaches based on three main stages introductory study, model development and model validation. The data collection uses observation as well as interview guidance and study devices evaluation sheet. Data analysis uses qualitative and quantitative techniques. The main conclusion of this research outcomes is that Social studies learning model based on the developed classic batik art and cultural values model has met the study model development principles and it has been proven to significantly improve competency and strengthen student character and identity if it is compared to conventional model
\end{abstract}

Key words: Cultural value, character, nation identity

\section{Introduction}

Since the establishment of social studies, in the first 2oth century until now, there has always controversy concerning the nature, objective, and content of social studies curriculum. Various groups competece each other to determine the most suitable framework of objectives for social studies curriculum whether using social study approachess, dicipline, history and geography, or action for social justice (Evans, 2004; Hursh \& Ross, 2000; Ross \& Marker, 2005; Thornton,

1 Dra. Sariyatun, M.Pd, M.Hum, lecturer in in History Educational Study Program, Social Science Education, Teaching and Education Faculty, Sebelas Maret University, Surakarta UNS (Universitas Negeri Surakarta). For academic interest, the author can be contacted through her home address Perum Mojoasri Blok A No.7, Mojosongo, Surakarta, her e-mail address: sari_fkip_uns@yahoo.co.id. 
2004). Therefore, Social studies curiculum is the most inclusive of all subjects in school (Stanley \& Nelson,1994: 266). National Council for Social Studies (NCSS) has explained the followings.

«Social studies are the integrated study of the social studiess and humanities to promote civic competence. Within the school program, social studies provides coordinated, systematic study drawing upon such disciplines as anthropology, archaeology, economics, geography, history, law, philosophy, political science, psychology, religion, and sociology, as well as appropriate content from the humanities, mathematics, and the natural sciences. The primary purpose of social studies is to help young people develop the ability to make informed and reasoned decisions for the public good as citizens of a culturally diverse, democratic society in an interdependent world "(1994: 3).

Social studies is sufficiently a comprehensive subject that address and solve national and social issues in Indonesia that is relevant to with the ability and development levels of students (Soemantri, 2001: 92). As a subject in schools, social studies is more educative than academic. The coverage of social studies material and objective is wide and therefore social studies study principles should be considered in order to make this subject valuable for students. As explained by Stahl (2008:2) in NCSS journal who explains the principles of social study (social studies) in his research entitled A Vision of Powerful Teaching and Learning in the Social Studies: Building Social Understanding and Civic Efficacy " He has stated that: First, Social studies teaching and learning are powerful when they are meaningful. The students learn to connect knowledge, confidence and attitude obtained from the class and outside the class. The value of subject material content is lead to how to present it to the students and how to develop it by a series of activities. Second, social studies teaching and learning are powerful when they are integrative. Third, social studies teaching and learning are powerful when they are value-based. Fourth, social studies teaching and learning are powerful when they are challenging. Students are expected to achieve learning objective individually and in a group by critical and challenging thinking activities. Fifth, social studies teaching and learning are powerful when they are active. An active social studies learning is signed by the ability of students in reflective thinking and decision making during the learning process. Students develop new understanding through active learning process that is by constructing social knowledge.

The reality is social studies learning has lost the spirit of educational process that is able to provide contribution to nation character education that can create a good citizen, whit having social wisdom and skills and a citizen who realize her/his identity. In modern vision, reason is ackowledged as primary source of knowledge that is resulting universal truth. Modern people as "homo sapiens" who has brain (sense) and known as hidden domination tools of imperialism and capitalistic hegemony. The implication to education and educator assignment 
is to discover and develop human intellectual ability and therefore they can maintain, preserve and develop human life to be more civilized and dignified (Rasyidin dkk, 2009: 73-76). The impact is social studies learning becomes full content, cognition, and recitation. Social studies learning has been stucked only to the information collection process and fact accumulation, recitation, taught in a boring, and not interesting and considered as heavy burden for the students. Community considers that social studies is not important and significant because it is not included in the National Examination and it is not useful for real daily life. Positivism modernism paradigm is also strengthen the community views. (Doll, 1993: 172).

Learning and study prioritizing teaching material mastery tends to ignore moral values and character development as well as less meaningful for living and students life. The learning and study ignoring character development has lost the spirit and essentially as the real education process which educaties the nation and state where the community live in order to be the more dignified nation.

Early finding of this research supports the previous research results that prove social studies is too full content with only limited time, and therefore the focus for the teachers is to the materials and the learning system based on result but not process orientation. The learning is monotonous, less contextual, and boring. Specifically, students humanity dimension has been ignored and the affective approach is started to be abandoned.

A number of research concerning social studies learning including Hasan $(1993 ; 1996 ; 2002)$ considers that social studies material is less containing social, culture, and students daily life issues. Social studies education is more oriented to the mastery of knowledge structure (knowledge source) than cultural social reality as reference value for students. Therefore, it is too full content and less suitable with the study motivation and orientation. Research result of Lasmawan (2008), shows that: social studies teacher tends to be bond by text book including the content, material order, examples and practice problems rigidly. However, the book is not suitable with the curriculum standard and students study needs. This condition causes the ignorance of students needs and interest. Research result of Farisi (2005) explains that the low appreciation of Elementary School students to social studies is as a result that the social studies subject is hard to be understand and social studies study is only recitation.

One of obstacles for the powerful and meaningdul social study learning is caused by the low position of social studies in curriculum. Most of the school considers social studies study is not important and significant. Research of Leming, Ellington, and Schug ( 2006) through National Representative Board conducted to more than 1,000 social studies subject teachers in year of 2005 in Indiana and North Carolina has proved by the low position of social studies subject in curriculum. This finding strenghtens survey result of Phillip J. Van Fossen (2005) to 600 teachers in Indiana mentioning that social studies is on the fourth place of main subjects after reading/language art, math, science and 
social research. Survey result of Maria E. Hass and Margaret A. Laughlin (2001) to 98 elementary school teachers, who were also member of NCSS, have mention that social studies teachers are placed as teacher in low school. Social studies is only integrated in reading/art language, math and science which are the main discipline in Elementary School curriculum.

Until now, the learning is completely focused to the final product of learning process which is a score standardized by linear and centralistic curriculum planning. Education process only results massive products that have been indoctrinized by competency based education system. Teaching curriculum is too complex to achieve the objectives that have been determined within linear method. Moreover, class is the study place of various students and therefore it will be impossible for subject planning based on the standard that has been stipulated and the same method for all students (Patrick Slattery, 2004: 58).

In his tough context, the ideal curriculum construction should be anticipated and preparaed for national education realization. Until now, the national education curriculum is not completely able to become an effective instrument yet for the realization of ideal national education empowering Indonesian people and community. Effort in ability quality has been limited the to growth and development of various ability as the reflection of various culture. This condition has caused the lack of politeness, ethics and creativity of children of the nation and become a phenomenon that require serious attention especially in managing and arranging education system in Indonesia. Education world always gets critics because it is seemed as not capable to create the qualified graduates who are complete as Indonesian human and as the noble goal of nation and ordered by Education Laws. As the consequences, counterproductive occurs in realizing nation noble goals and causes the ignorance of values and moral in social life manners within a civilized community. Modernity has lead education world to the technicalistic mechanic problems. Specifically, students humanity dimension has been ignored and affective approach has started to be abandoned. In conformity with the condition, Abdullah (2008) explains that until now, education is only lead to the creation of knowledge and technology ability and therefore school world has no difference with the machine producing the graduates who have lost their humanity side.

Education process lead and directed only for ratio and rationality logical reasoning interest will cause humanity disaster in modern community. As explained by Hasan (2002), an expert and educational researcher of social studies, all of them are caused by education process is only a knowledge transfer and not building students character. Students are not given any chance to reflect and position themselves because education system is solely oriented for work world interest. Education is only led and directed to the creation of knowledge and technology ability and therefore the teaching burden is led and directed to the field mastery. As explained by Drost (1998:74), education should be organized as the tool to humanize human. The lifting of valence and dignity is not only played 
by ratio logical reasoning but also integration between rational logical readoning and spiritual logical reasoning. Within the context, it is not exaggerating if national education concept for students ability development also leds to three basic abilities which are cognitive, affective and psychomotoric. Incapability to develop the three fields will create imbalance education out put.

Within such condition, postmodern provides alternatives for education process. The first postmodernist ideas originator is Arnold Toynbee in year 1939. Charles Jencks ( 1986) confirms that the creation of postmodernism concept is coming from a writing of Spains Frederico de Onis, into Antologia de la poesia espanola e hispanoamericana introducing postmodernism terminologies to describe reaction in modernism coverage ( Siswanto, 1998: 159). The end of modern philosophy which is way too totalize human life has significant correlation with deconstruction process. Deconstruction from Jacques Derrida (2001) develops to be the main power of postmodernism. Education deconstruction is focused more to reveal institution hegemony which is used by media to maintain status quo until now. Deconstruction is led and directed to against dominant education ideology, rigid and inhuman teaching practices and destroy institution and teachers authority.

Mastery and mechanic regulation rules provides a way for new paradigm that is able to mobilize individual in using ability to analyze and solve issues from variuous perspective and able to cooperate with various groups as explained by Suarez Orozco and D.B . Hillard,2004 : 18-24.

Globalization's increasing complexity necessitates a new paradigm for learning and teaching. The mastery and mechanical regurgitationof rules and facts should give way to a paradigm in which cognitive flexibility and agility win the day. The skills needed for analyzing and mobilizing to solve problems from multiple perspectives will require individuals who are cognitively flexible, culturally sophisticated, and able to work collaboratively in groups made up of diverse individuals.(Suarez Orozco dan D.B . Hillard,2004: 18-24)

As the effort to improve education quality, it is necessary to consider curriculum reformation. Educational institution must be able to provide score, knowledge and various skills for the students to participate in anticipating globalization impact. The two most influenced philosophy in curriculum study are after structuralism and deconstructionism. Both of them has the same objective and goal with postmodernism which is making an effort to handle damage as a result of modernity by new concept in culture, language and authority area. Postmodernism offers theoretical paradigm based on critical thinking, reflective intuition and problem solving. In the other side, postmodernism is based on the new knowledge which is complex, multi dimension, eclectic, relational system and interdisciplinary namely curriculum as an open system (Davies, 1990:110). 
Students based curriculum providies opportunity for students to systematically get involved in decision making concerning social, economy, politics and personal isses. Teachers will play as central role as evaluator and interactive mediator in this process. The focus is to assist students to develope intellectual ability and social power through dialogue and constructive critics. Study and understanding are performed by dialogue and reflection between teacher and students. Curriculum is based on the needs of students and not on the valuable things for students ( William Chan, 2009: 4). As explained by Giroux (1993: 52 ):

Educators in the postmodern era will no longer be able simply to "teach" history as facts to be memorized. Because the autobiographical, local, and particular are essential in order to understand history, teachers will now haveto listen to students and their life stories - encouraging football, art, or other student interests.

The use of postmodernism paradigm which is critical and reflective will support an interesting discussion and provide understanding to the social issues developed in local and global environment (Massialas,1963:xiv). Curriculum is no longer understood as the closed documents but also a constructive networks that connect one another and are meaningfully created by student and teacher interaction. The more dots connecting the network, the wealthier curriculum will be. As explained by Doll in his book entitled A Post-Modern Perspective on Curriculum (1993), curriculum as a praxis can be constructed in non linear matrix and as transformative curriculum that enablies teacher and students to develop dialogic process concerning to the learning materials (knowledge) as an openended process and in form of non determinist construction.

According to Doll (1993: 176 - 183), in order to construct transformative curriculum as a praxis, four $\mathrm{R}$ elements are used: richness, recursions, relations and rigor Richness element enables teacher and student to have reflective thinking by various methods to obtain and understand meaning from various perspectives. Study is a social contex and knowledge as a social construction and therefore curriculum is a social contextual process. This thought enables teacher to accomodate student various culture and social environment to the classroom as an effort to meet recursion element which enrichies curriculum in order not to be apart from students culture and social contexts. Therefore, social studies study process is not only teacher knowledge authority but also considers daily experiences of teacher and student in school. In order to achieve this objective, social studies classroom must be changed to decision making area that involvies students and teachers critical and analytic dialogue using traditional material, text book, letter and contemporary events in students environment. (Doll,1993:. Xiii)

School must provide suitable condition and therefore students are able to "identify critical issues and learn to find the problem root and its consequences 
for themselves, family, community and country and even world community. As explained by Greda Wever Rabehl (Kumar, 2009: 143) that social studies study is less giving attention to gender, sex and sexuality issues which will grow consciousness of variety and social justice becomies concern in education. The importance of considering the wider political social context is also said by Nieto (2004:4) that:

It is clear that no single explanation (of academic achievement) is sufficient to explain why some students succeed and others We need school achievement as a combination of personal, cultural familial, interactive, political relational and societal issues and this means understanding the sociopolitical context in which education takes place

The implementation of depth elements or curriculum enrichment of social studies is relevant to the main objective of social studies subject which is «to assist the youth to develop the ability in decision making for the purpose of public ineterst as the citizen of democratic society having various culture and in the dependence world ( NCSS ,1994: 3). Based on social studies subject, individual develops multi dimensional character by acknowledging himself/herself and her/ his environment and obtains some skills including creative thinking and problem solving.

Social studies study is not end at the test performed or the assignments submitted but the activities must be considered as the initiation of reflection and develop any new things in opened curriculum praxis. Bruner (1986) said that "every formal theory of mind is powerless without recursion" and confirmed the importance of recursion for epistemology and pedagogy. Doll emphasizes that "recursive reflection" is in the heart of transformative curriculum because recursion is aimed to develop competency to organize, combine, ask and interpret heuristically. Teacher must start social studies learning with including cultural social context of the student (contextual) and involving students in this process.

The development of ideal social studies study should integrate cultural values in the community. Every person lives within community context and therefore confidence and understanding of truth comes from the community where the person lives resulting various truth. Postmodernism consciousness has realtivism and pluralism characteristic because confidence and faith issue is social context issue. In Surakarta and Yogyakarta community context, classic batik designs has philosophy meaning as "guidance and arrangement" symbol for relationship between human and God, community and nature (Kalingga,2002). Cultural values integration of classic batik is enabled as a result that social studies curriculum in school emphasizes to the major point of knowledge structure and human behavior model in the community. Therefore, social studies knowledge will have benefit for students life as individual and member of community. (Somantri ,2001: 92). It is relevant to the objective of social studies education particularly in creating students as a good citizen with various character based on spritual, 
personal, social and intellectual dimensions. School curriculum must assist the students to build and communicate knowledge, have positive attitude to the culture and develop ability as well as commitment to learn for his/her entire life.

In order to clear this concept, Jennifer Terry work can be taken as example concerning historygraphy of lesbian and gay community which is subjectively considered as deviation but within postmodern curriculum context, agressive behavior (female teenager) is understood and analyzed as masculine tendency. Furthermore, the objective of deconstructing history discursive practices concerning female teenager behavior is to assist teachers, counselors, adminstrators and authority official directly handle teenager issues. Until now, they are considered as naughty and bad students and as the students having deviated behavior and therefore they are marginized within school and community.

Relations principle, according to Doll $(1993: 179)$ can be seen from two aspects, pedadogy and culture. Based on pedadogy, relations principle is related to any things available in the effective curriculum structure in form of matrix or network and therefore it enrich curriculum content. Culturally, relations principle is related to the cosmology or culture relation outside curriculum forming and creating a big matrix attached to it. The relation is dialogic between the effective curriculum document with students cultural experiences. Social studies curriculum concept is Megaparadigmic, an integration signed by open process between race and gender in negotiating with others. Therefore, curriculum within relation context can be understood as :"composition of revealing and expressing: nothing but occur and always changed dynamically."

Rigor element is applied and implemented to make transformative curriculum is not falling to over relativism. Curriculum conception enables teacher and student to create independent and separate knwoledge space, taking the terminologies of Pinar (2004), it is called as "curculuum as currere". Based on critical and reflective discussion referring to : (1) what to do in the classroom; (2) how to design the activity (Mamabolo ,2004:1).

Implication in learning process must provide access to various discourses enabling students to defineherself/himself actively and challengingly. As explained by Foucault that the self determination is the same as freedom implementation. In conformity with Peter opinion (1977) that : education noble objective is to develop individual "becoming what she/he wants". Therefore, students are not only learning literature study but also participating in class discussion, getting their confidence back, satisfying needs and achieving their goal. Jarvis (1990) defines this terminology as "furnishing and improving confidence from individuals and therefore they are able to be the more successful and confident students and able to provide contribution for Country development. Curriculum must arrange the direction fro study and teaching by coherent, flexible and adaptable frame of work adapting with the change and various needs of students. School curriculum for the 21st century defines as study experience that must be given to students in order to achieve educational objective. 
One of the educational model forms able to maintain local and national community ability in supporting and validating "local knowledge" is by integrating local cultural values within learning context in school. Knowledge and understanding to local and national culture values that will form Indonesian people proud of their homeland and will manifest to nation identity. Nation identity can not be separated with nation identity/characteristic which becomes an option of reflection or viewing of nation character and accumulation or synergy of nation child individual character grouping to Indonesian nation (Kartodirdjo, 2000)

Principally, nation identity is cultural values manifestation growing and developing in a nation living aspect based on the characteristic of differentiating a nation with others. Classic batik as cultural outcomes meet three cultural forms: batik design idea and creation culture, physical culture in form of batik cloth artwork and behavior culture in form of the use of batik cloth as clothes in Indonesian people living activities. Djoemena (1986: 11) explains that every batik design creation always has symbolic meaning based on Javanese philosophy. At the beginning batik design was created, it was not all people can wear them. Therefore, the use of design is adapted and suited based on these two things : (1) social position within the community, (2) the opportunity and occassion for batik use and wear depends on the meaning and hope containing in the batik ornamental variety. Hitchcock adds (1991: 83-89), that classic batik design is related to the symbolic and philosophy meanings in Hindu-Budha culture in Java. Therefore, classic batik contains "guidance and arrangement"(Kalingga, 2002).

Classic batik presence as the guidance and arrangement that is standardized by the rules and regulation issued by Kraton Surakarta in the year 1769 by Paku Buwono III (1749-1788), as follows:

"Anadene arupa jajarit kang kalebu ing larangan ingsun: batik sawat lan batik parang rusak, batik cumangkiri kang calacap modang, bangun tulak, lenga teleng, daragem, lan tumpal. Anadene batik cumangkiri ingkang acalacap lung-lungan utawa kekembangan, ingkang ingsun kawenangken anganggoha papatih ingsun, lan sentaningsun kawulaningsun wedana". The form/design of jarit included in my restrictions are: batik sawat and batik parang rusak, batik cumangkiri which is a design of modang bangun tulak, lenga teleng, daragem, and tumpal. Batik cumangkiri is in a form of lung-lungan design or kekembangan (flower) allow to be worn by my governor, counted family, abdi dalem wedana

Culture positioning of batik as a symbol system contains the following four major issues: (1) cultural space limits influencing symbol creation and meaning to experience dynamic shift; (2) limits of culture determining meaning construction is influenced by authority relation involving a number of actor; (3) pattern of authority relation is manifested in group identity determining the way of thought 
of the group; (4) identity formed by a series of symbols is realtively experiencing shift of community change. The meaning shift of symbol system from time to time is debatable and constant".

The meaning of culture symbols becomes an object resulted by a negotiation process involving a number of constentant based on each interest. Therefore, the meaning produced by a symbol is varied based on the group and space as well as it is dynamically shifted based on time ( Irwan Abdullah,2009:4-6). Thus, the cultural symbol meaning is no longer a monopoly of new orientation centers building influence and reproduces old values for the new space and history context. Within classic batik context (vorstenlanden) which is full of philosophy messages, spirituality aspect and social relation hierarchy in feodalism era becomes media of authority legitimation or becomes monopoly of values orientation of Keraton Surakarta and Yogyakarta, and now they are reproduced deconstruction to character education values and as Indonesian nation identity. Basic conception of deconstructive thought is the thought idea placing all reality as determination signs. Within this context, the reality creation is determined by sign namely classic batik design.

The presence of batik in spatial-temporal dimension has passed the long period at the same age with the human needs culture to dress. Therefore, it is accurate to make "traditional wisdom" which is classic batik ad "product" to be consumed for the purpose of "self identification". Selection of "traditional image" (classic batik) in global community field by modernity symbols, in "dialogue and interaction' process to negotiate Indonesian identity before advanced countries is suitable. As explained by Abdullah ( 2006:34-35) that "Traditional wisdom' as Indonesian identity reflection is related to symbolic consumption process and becomes one of important and significant signs of consumer culture growth along with the creation of global social space. Symbolic consumption process is basically a part of identity creation process. Therefore, the goods consumed then represent the presence and image of any person or community .

In conformity with the question mentioned above, Friedman (1990: 312) has opinion that making "traditional wisdom" from classic batik design as "product" for the purpose of nation identity creation is cultural strategy of selfdefinition. 'Traditional wisdom' refers to the opinion that perfection of form in Indonesian culture and traditional art are not an artistic supremacy symbol as effective in the west but they are based on trancendent value beyond aesthetic coverage. Within this perspective, art becomes a medium to achieve the higher living totality, the thing that can not be achieved by West modern art failed to answer human existence issue.

The meaning of culture is open to other meaning and it means it is continously growing and developing and therefore the theory must be redefined, reality must be deconstructed, and culture phenomenon must be interpreted based on the meaning of plurality. Symbolic expression of culture is not always a cosmology statement or the same value because orientation center is formed in a polycentric 
way. This matter shows a deconstruction of traditional authority relation that the culture centers are no longer having dominant power to deremine character of social space. The country takes the role with space redefinition to support a pattern of authority realtion. Giddens calls this as reproduction of locality which is redefining of space to guarantee preservation and group authority who rule. (Appadurai, 1996) The meaning of cultural symbols is becoming an object produced by negotiation process involving various groups with various interests. Therefore, the culture formed must be seen as differential culture growing from continous human interaction (Friedman,1995. Miller,1995).

Batik is able to survive across the era and becomes a heritage legacy. Therefore, there are two things to be observed. First, critical of batik sociology dimension will be used to see how batik culture is understood in consciousness within contemporary community. Second, critical of academic dimension to observe how the real batik philosophy values obtain space as study discipline. Perspective on academic dimension of batik is urgent because education dimension is one of pillars for strengthening nation identity (Kasiyan, 1980,: 3).

In critical education perspective, education must be able to open insight and horizon of thinking of students and teacher, and create space for students to identify and analyze freely and critically their world structure for the purpose of social transformation. Both sides must go from the understanding that each has experience and knowledge and therefore dialogue and offering their knowledge to one another are required. As the effort to grow motivation and participation of students, learning is designed creatively and meaningfully as a result that learning occurs in a community and study result will also be implemented in certain cultural community. Within this context, classic batik local cultural values integration in learning is one of the creative learning designs in order to produce the meaningful learning contextually. Cultural value based learning approach provides opportunity to the students to create meaning and achieve integrated understanding to knowledge information and the knowledge information implementation within cultural community context (Sutarno : 2004).

Based on the background mentioned above, development research is conducted. Generally, research is aimed to construct social studies learning based on classic batik local cultural values to strengthen nation identity using postmodernism view of understanding curriculum as a praxis. Based on the construction, this research is ableto empowertheresearcher, socialscienceteachers and students. It is based on the thought that education must cover the three human interest. First, education is aimed to make human able to control the environment by knowledge and technology in order to support human welfare, however, it is also able to destroy and damage human. Therefore, education is "responsibility ethics". Second, education assists students in developing communication ability with colleagues and past generation by history study and reinterpreted tradition. Ability to interpret history and tradition is very important and significant in the effort of developing self identity. Third, education accustoms people to be critical 
to various determinism and authoritarian or tatlitharian actions. Education is also understood by any values and behavior that are intentionally implanted to the students (transmission of values). Therefore, it is expected to be able to make them becoming a good person or having good behavior as a result of good values support. .

Therefore, social studies education curriculum development is required based on teacher and students investigation concerning the most basic things for theory life which is any matters to be experienced, to be known and any matters to have most benefit for students and their social environment (Schubert, 1991: 114). It is as a result that social studies is the knowledge discpline which is always related to the community social issues. Social studies teacher should be able to present community real issue and to make the classroom as media and study tools for students. According to Luchan (1990), social studies learning is the development of students living practive in community. Therefore, the most important and significant thing is how to make students learn so that study meaning will become an actual reality in every student.

As explained by Greda Wever Rabehl (2002:143) that social studies curriculum and learning disconnected from social reality context are as a result of abstract thinking domination and the lack of understanding to social reality filled with pain, violence and injustice. The implication is that social studies education must provide conscious understanding of the students concerning diversity and differences issues within social environment. Therefore, curriculum development in school must integrate such issues. As explained by Gardner (2004:263) that:

Education's challenge will be to shape the cognitive skills, interpersonal sensibilities, and cultural sophistication of children and youthwhose lives will be both engaged in local contexts1 and responsive to larger transnational processes. We claim that two domains in particular will present the greatest challenges to schooling worldwide: the domainof difference and the domain of complexity.

Therefore, social studies education is aimed to assist students in controling themselves in social life and provide description and illustration concerning values and how to implement values in community. The implication is that social studies is expected to be more focus to the building of character values, social behavior and social skills and to form and create students to be citizens having social awareness and social skill in community. In conformity with that, Supriatna (2007:2) mentioned that social studies learning formulated in curriculum must have important and significant role in preparing students to develop the values of hardwork, economics, honesty, discipline, love of oneself and the environment. Social studies education must be able to develop critical thinking ability by using various problem solving methods; social studies as personal development of the individual and to equip ability for self development by various social life skills

Student as "subject of education", as well as the <use" and "the ultimate target, whose existence and any and all abilities must be acknowledged and 
appreciated (Sumaatmadja, 2002). Teacher should place themselves as developer and curriculum implementer in the class room as a result that the success of curriculum implementation in class room depends on the teacher. (Shaver, Davis, \& Helburn, 1980). Based on this perspective, teacher as the partner of social studies curriculum development, then curriculum improvement depends on the teacher (see Cornett et al.1992; Kesson \& Ross, 2004; Parker \& McDaniel, 1992)

Within this context, classic batik local cultural values integration in social studies learning is one of creative learning designs in order to produce the contextual meaningfull learning. Cultural values based learning approcah provides opportunity for students to create meaning and achieve integrated understanding of knowledge information obtained as well as implementation of knowledge information within cultural community issues (Sutarno : 2004). Generally, research is aimed to construct social studies learning based on classic batik local cultural values to strengthen nation identity using postmodernism view which is understanding curriculum as a praxis. Based on the construction, this research is able to empower the researcher, social science teachers and students. It is based on the thought that education must cover the three human interest: first, "responsibility ethics", second, education assists students in developing communication ability with colleagues and past generation through history study and reinterpreted tradition. Ability to interpret history and tradition is very important and significant in the effort of developing self identity. Third, education is defined as behavior and values cultivation (transmission of values) and able to make students becoming a good person or having good behavior as a result of good values support.

Educational values is neither indoctrination or direct cultivation of any matters determined as "true" (values) but education must support critical and reflective thinking and therefore it produces creative response to value situation. This educational process enables students to be able to make rational choices and responsible behavior. Therefore, implementation of social studies education model based on classic batik local culture for character strengthening is developed through by cooperative learning model and values clarification. It is to respect students autonomy, support students to have critical and reflective thinking in making rational values choices and responsible behavior. As explained by Robert C. Scharff and Val Dusek (2003: 344-351) that knowledge concerning the world comes from interpretation, mainly, and therefore human basis is thinking and human essence is finding and interpreting.

Social studies education can not be disconnected with values and norms effective within a nation. (Batik cultural values and its relevance with life). The meaning of social studies learning is achieved in the event that the teacher packs the material up relating knowledge, faith and behavior obtained in the class room and outside the class room (contextual). As explained by Black and Broun (1939), that «one of the characteristics of social studies education is values development and analysis as well as its implementation to social action. 
Previous explanation is relevant to Postmodernism concept that students must be critical in facing problems and finding the perspective and problematic meaning ( Muhadjir, 2000:237). Truth is relative as a result that any and all knowledge is created or "built" in people's mind. Truth using "perspective" "construction" or "viewpoint" is how the view points of various groups in seeing the world. Knowledge consists of "construction" (the way to see world) and not "truth". Knowledge and language are created by human not as a result of "true" but "useful". Cultural social reality is constructed by human and therefore there is no objective reality because all version is only human creation. As said by Watch (2002) that :

\begin{abstract}
A key word to learn when trying to understand postmodern education is constructivism. Constructivism is the main underlying learning theory in postmodern education. The basic idea is that all knowledge is invented or «constructed» in the minds of people. Knowledge is not discovered as modernists would claim. In other words, the ideas teachers teach and students learn do not correspond to «reality,» they are merely human constructions. Knowledge, ideas and language are created by people, not because they are «true,» but rather because they are useful.
\end{abstract}

The excellence of cooperative learning can improve students performance in academics assignments, excellence in assisting students to understand difficult concepts and assisting students in building critical thinking. Values clarification approach provides emphasis to first the effort to assist students in studying their feeling and behavior in order to improve the consciousness concerning their own values. Second, the ability to communicate openly and honest with other people, related to their own values; Third, the ability to jointly use rational thinking ability and emotional consciousness in order to understand their own feeling, values and behavior pattern ( Hersh,1980 ). IBNBBK learning model is expected to be one of the solutions to meet score, chalenged and meaning based social studies learning ( Sthall, 2007). Specifically, learning model developed is expected to support learning objective in accordance with the Competency Standard and Basic Competency as well as nation caharacter and identity strengthening

Therefore, the necessity of classic batik local culture values integration in social studies learning is based on : first, understanding the local wisdom values that may become a filter to the foreign culture influences that have the impact to the shallow understanding to Indonesian values. Second, reality that education meaning narrowing occurs lead to create and form solely the individual smart person and ignore spirituality aspects that are able to create students character and nation character namely collective identity (Kartadinata, 2009). Third, education organization recently remains to be dominated by various dogma, doctrines or teachings obtained from west. However, culturally, education organization must be taken from Indonesian nation noble values ( Alwasilah, 2009). Fourth, hegemony and modern superiority not giving sufficient space for local narrations 
development. Social studies learning based on classic batik culture values will be useful in nation cultural values building (environment/regional). In addition, it also develops social behavior and social skills related to the chosen values actualization. Therefore, it will lead the students to be citizen who have social awareness and social skills as well as develope tolerance in daily life.

Based on the explanation in research issue background, the research issue formulation is: How does social studies learning model based on classic batik local culture able to improve competency assignment and strengthen nation identity? In conformity with the issue formulation mentioned above, the objectives of this research are (1) To describe social studies learning condition in Surakarta Junior High School implemented until now; (2)to develop social studies learning model based on classic batik culture values able to develop competency and strengthen students identity in Surakarta; (3) to design implementation of social studies learning model based on classic batik culture values able to develop competency and strengthen students nation identity; (4) to have knowledge concerning affectivity of social studies learning model based on classic batik culture values in developing competency and strengthening nation identity .

\section{Research Method}

The research is aimed to develop social studies study model in Junior High School based on classic batik local cultural values which is able to strengthen nation identity. The operational objective of this research is to obtain experience truth (empiric) situationally from the teachers in social studies learning model development in the effective class of Junior High School in Surakarta. IBNBBK learning program is designed based on the specification of classic batik art local cultural values integration in social studies learning for nation identity strenghtening. Based on deconstruction theory, symbolism values in classic batik designs containing manners notability is deconstructed to educative values which are able to be used as media and tools for students character strenghtening.

In order to construct social studies learning based on classic batik local cultural values in postmodernism view concerning curriculum as a praxis, $4 \mathrm{R}$ elements can be used: richness, recursions, relations and rigor developed by Doll (1993: 176 - 183). Model implementation is developed by Cooperative and Clarification learning model.

Data collection is the combination of survey and interview creating "between method"(Creswelt,1994). Thecombination of qualitativeandquantitativeapproach in research is complementary approach (Thomas,2003,6). Therefore, character difference from two approaches provides utilities. Two phase design model enables two design development theoretically and practically in complementary position, equally and sequentially. Implementation of combination approach is not ignoring qualitative and quantitative research tradition epistimology and also theoretically but solely conducted for the effectiveness of procedure implementation and research outcomes 
According to Richey \& Nelson (1996), this research includes a developmental research type which is the research having orientation to product development namely social studies learning model based on classic batik art local cultural values for the purpose of nation identity strengthening. Research and development approach is considered as suitable to be used because the objective is not only finding learning implementation profile but also developing effective and adaptable learning model in accordance with the real condition needs in school. This approach has excellence in the event that it is seen from the work procedure while noticing more to the needs, systematic and cylical as well as real situatation in school.

Research and development developed by Borg and Gall (1989: 781-802) is based on field data, field testing result and revision. $\mathrm{R} \& \mathrm{D}$ includes the stages in form of cycle until objective definition is obtained similar to the cycle of "class room action research spiral" (Hopkins, 1993, 48) which is "involving teachers using methods to study classroom problems" (McMillan dan Schumacher, 2001: 20). It is emphasized by Borg dan Gall (1989: 783) that the model developed should be "real-life", efficient and objective realistic in a series of subject model (Borg dan Gall, 1989: 797). The research and development stages developed by Borg and Gall consist of ten steps but for the purpose of dissertation, the researcher make the research and development stages simpler to : 1) pre-survey; 2) model preparation/development; and 3) model validation.

\section{Implementation of Research Stages \\ 1. Pre-survey}

Preliminary study which is a research and information collecting activity that has two main activities namely literature study (literature review and previous research result) and field study. Field study includes: first, observation is conducted in Public Junior High School 9 and Public Junior High School 3 as Public Junior High School group (A), Public Junior High School 7, Public Junior High School 10, and Public Junior High School 19 as group Public Junior High School(B), MuhammadiyahJunior High School 2, and Kristen Junior High School I as private Junior High School. Learning model component developed by Joyce (2011) is used as reference in considering social studies learning implementation in the field. Result of this activity, the learning system implementation profile is obtaine especially related to the social sceince learning activities.

This research is qualitative research and therefore the research instrument for data collection in first phase is researcher as main instrument (Wiriaatmadja, 2005). In order to facilitate researcher in collecting data, supporting tools are used in form of field record, tape recorder and camera (Hopkin ,I993; Madya,1994 ; Maleong, 1997). The implementation of data processing and analysis of qualitative design result is initiated as data collection of research background and intensively implemented after leaving the field. Data processing and analysis activity are 
related to collection, reduction, categorization, codification and verification process.

\section{Model Development}

Based on the preliminary study findings, IBNBBK learning model is prepared to be implemented in social studies learning. The stages of learning model preparation includes some activities as follows:

a. Preparation of rough draft model. The basis of preparation used is philosophy basis model, pedadogy, theoretical and empirical or implementative feasibility.

b. Model testing. The method used is action research. This action research is implemented collaboratively and participatively (Wiriaatmadja, 2005: 83). Essence of action research is at the teacher as the researcher within context of structure change and education process (Hopkins;1993). Partner researcher takes the role as facilitator and consultant to teacher thought concerning his/her activities and teaching practice. Facilitator role is assissting teacher to formulate diagnoses and action hypotheses that will be tested empirically in the class room and therefore colaborative strategy can provide comfort to the teacher in performing diagnoses and implementing learning plan for the purpose of valid data collection and analysis. Recycling in class action research is initiated by action planning, action implementation, process observation and evaluation as well as reflection, etc until the improvement expected is achieved as seen in diagram 3.1 as follows :

c. Model main revision. Based on model testing result, in the event of necessary, revision, perfection and adaptation will be performed before model empirical validation.

\section{Quasi Experiement}

Empirical validation model is constructed using experimental design (Creswell, 1994: 130-134). The most important thing to be found out in this final model validation stage is the impact of learning model for social studies based on classic batik local cultural values in Junior High School for the purpose of nation identity strengthening.

The use of experimental model in this stage is caharcterized by the implementation of control class and experiment class separation to be tested by pre test and post test. After that, the difference of average score between control group and experiment group will be compared (Gall,Gall \& Borg, 2003;402403). In addition, questionaire will be distributed to the students in order to have knowledge concerning the impact of learning support for social studies subject based on classic batik local cultural values in Junior High School for the purpose of nation identity strengthening. 


\section{Research Result and Discussion 1. Theoretical Framework of IBNBBK Model Development}

"IBNBBK" learning model development uses Post modernism paradigm. Postmodernism philosophy is used as theoretical basis for : (1) social studies learning deconstruction undergoing until now based on modern curriculum; (2) classic batik local cultural values deconstruction which at the beginning used as media for aristocrate group within feodalism community environment in Surakarta becomes character education media integrated to social studies learning; (3) Classic batik as media to negotiate Indonesian identity (classic batik) to global social space. Selection of "traditional image" (classic batik) in global community world was filled by modernity symbols in 'dialogue and interaction' process in order to negotiate Indonesian identity before advanced countries;(4) Classic batik cultural local wisdom within cultural resistance context is understood as deconstruction is based on globalization meaning having global knowledge and insight and acting and behaving locally in accordance with nationality context. One of cultural resistance components as cultural capital is classic batik, in this case.

Postmodernism educational perspective is relevant to the mission and objective of social studies education that is having role in good citizenship behavior creation, and also a reflective effort in social studies education can be a social living critics (social studies as social criticism). Strategy of "IBNBBK" learning development provides the students knowledge, skills, behavior and values and therefore it creates image to be a human having identity and able to live in the middle of community environment. One thing that can be implemented is the existence of local culture values integration within students environment (cultural values from classic batik) in social studies learning. Based on values clarification learning, students thought "ethical relativism" and how human develops their own values. Process of values finding by students based on values clarification will be equal in the creation of spirit and common goal for collective welfare as core values. Model implementation will support the growth of tolerance and appreciation to multi culturalism as well as fair acceptance to race and gender differences.

“IBNBNK" learning model development as social studies education strategy which is multidimensional and able to provide and support knowledge transfer, nation culture values infiltration and moral in practice world and therefore it can grow and develop knowledge wisdom, attitude and behavior consciousness (mode of action) of students to the diversity. The process will make social studies knowledge able to have tolerance in co-existence framework and furthermore, able to participate in creating social relation which is pro-existence in social, culture and religion diversity in Indonesia.

Theimplication of constructivism study theorybased on model development objective using values clarification is developing cognitive dimension or rational 
ability (sorting and selecting values) ; (2) affective dimension (appreciation and pride), (3) values psychomotoric dimension (continous and patterned concrete action). At the end, values internalization built by the students will occur. Therefore, study and learning process is not only stopped during learning in school but continue to going on within social environment. The use of humanistic study theory is based on the study objective which is humanizing human being. Study process is considered as success in the event that the students understand the environment and himslf/herself. Students, within the study process, must make the effort and therefore she/he is slowly able to achieve the self actualization accordingy and properly. Teacher role is to become facilitator for students while teacher provides motivation, consciousness concerning study definition within students life. Students have role as the main actor (student center), define his/her study experience process and understand as well as develop his/her potency positively. Study paradigm centered to the needs of students is the prerequirements to make improvement and development for the Country (Aldrich :2009:57). According to Stein (2000), there is a shift of meaning of «know» «from able to remember and repeat information to "able to find and use them «. Education empowerment enables students to express their opinion with more confident way « (Wiggins ,2004: 10).

Based on the explanation above, the implication to IBNBBK model is that learning activities are identical with students activities optimally. It is not sufficient only by hearing and seeing but it must be based on hands-on, mindson, constructiveness and daily life (contextual). Humanistic technique is aimed to open "Open Area" of the students to grow more confidently and know themselves more by information giving and receiving process concerning themselves and other people. A good learning must have understanding and involving emotion and values on them. Information delivery and absorption process must also be implemented.

\section{Preliminary Study Result a. Social studies Learning Condition of Junior High School in Surakarta}

The finding of preliminary study result implemented by observation and interview can be grouped into three learning process model. The first model is teacher domination in learning activities is very important and the students only sit and record. Class situation seems quiet and even silent unless the teacher's voice explaining learning material. Learning undergoes in linear way without any material development except students text book. Teacher controls the material (economy activity) and therefore he/she can explain the learning material in detail and students only opens the text book and listens teacher's explanation. Some students record teacher explanation but mostly just make a note in the text book. Teachers are not using any learning media because the examples are mentioned verbally. 
The second type is teacher domination is significant, however, the teacher is able to support the students to ask and respond the teacher's explanation. Eventhough it uses lecture method and question and answer session, the teacher is able to make the learning within daily life context (examples of economy activity). Students and teachers participation in learning is performed sufficiently balance because teachers are able to support and stimulate participation of every student to ask make examples and respond to their friend's question.

The third type is teacher domination is less, students are involved in learning activity. During disscussion, teacher facilitates students to colaboratively study and suggests the students to use various sources. Every group has been able to tell the group work result but also it remains text book without interpretating or evaluating and positioning themselves to the existing figures. They have not been able to show the values capable to be developed from history events and its relevancy with daily life. Teachers provides less strengthening to the values during confirmation and closing.

\section{b. Opinion of Teacher and Student to IBNBBK Model Development}

One of social studies objective is to make students sensitive to their environment/culture and therefore students do not feel isolate with their environment and even able to contribute in maintaining and preserving their ancient culture heritage. Therefore, social studies teacher is responsible for cultural values inheritance to the students. Social studies teacher agrees and supports classic batik cultural values integration in social studies learning. It is also relevant to the teacher thought that social studies has role in strengthening nation personality and identity because one of social studies objectives is to make students becoming good member of community and good citizen.

The problem is teacher experiences difficulty in carrying social studies learning material and design integrating cultural values in RPP and during learning implementation. Teachers suppot the model development idea and are willing to colaborate to develop social studies learning model based on classic batik local cultural values for the purpose of nation character and identity strengthening. "IBNBBK" model development idea is also supported by students opinion that social studies subject will be more interesting in the event that teacher facilitates students to understand the values, be able to be modeled and avoided from the discussed subject material. They also have same opinion that batik is Indonesian nation identity and therefore the existence is necessary to be learnt and maintained.

Therefore, this model development based on social studies, is needed by teacher which is developing powerfull and meaningfull social studies learning which is charaterised by integrated, score-based, challenged and active. In addition, it is also supported by the willingness of teacher, student and school principal to develop IBNBBK learning model. 
"IBNBBK" model development idea is also supported by students opinion that social studies subject will be more interesting in the event that teacher facilitates students to understand the values that are able to be modeled or to be avoided from the discussed subject material. They also have same opinion that batik is Indonesian nation identity and therefore they do not agree if Indonesian batik is acknowledged as one of Malaysian culture wealth. As Indonesian people, they are proud wearing batik uniform. Batik is the nation cultural heritage and Indonesian nation identity and the existence is necessary to be learnt and maintained.

\section{IBNBBK Model Development}

This model development remains to refer to five learning components explained by Joyce, (2011) consisting syntax, social system, reaction principle, supporting system, instructional impact and supporting impact. The early forms of metacognition based learning model for the purpose of students competency improvement of social studies subject are as follows:

\section{a. Syntax}

Generally, the objective of IBNBBK model development is to make students critically able to find the values which areable to be modeled from learning material. In addition, model is expected to be able to provide meaningful effect to students character and behavior strengthening to batik as nation identity. In order to build consciousness and develop ability of the students in identifying their own values and other people values, therefore the implementation of cooperative learning is combined with Vaue Clarification Approach (VCT). The combination of this learning model is on the basis that the moral development is strongly related to cognitive development and social interaction result. "IBBNBK" model builds and develops students ability and therefore they will be able to understand and find morale values in smart way in their social dynamics interaction. This approach will assist students in understanding and finding utimate meaning and values of any events.

IBNBBK" model syntax developed in the combination of cooperative learning and value clarification. The combination of two learning models, in the implementation, remains to refer to learning model based on Regulation of Ministry of National Education number 41 year 2007, consisting of three stages of learning: (1) Apperception ; (2) Core consisting of Exploration, Elaboration, Confirmation and (3) Closing.

The seven steps of value clarification show and reflects the integrity of productive and efficient educational dimension and it is simplified to three steps. It is aimed to make teacher easier in evaluating and providing strengthening ofevery learning activity stage. The first to third steps include cognitive dimension 
(emphasizing rational ability). The fourth and fifth steps reflect effective dimension (appreciation and pride). The sixth and seventh step show and reflect psychomotoric dimension (continous and patterned concrete action).

\section{Orientation and Apperception Stage}

Teacher conditions the preparation of students to study and provide explanation concerning learning objective, material topic to be learnt, and knowledge of students to the material previously provided. This orientation stage is very important in relation to the implementation of IBNBBK model, media preparation and study sources supporting model implementation. This activity is performed as the effort to avoid confusion between teacher and students in implementing IBBNK model. In the early activity (including apperception) as a result that, in this stage, teacher explains (1)concept of value and its function for individual and community living; (2) value source including from culture which is philosophy values of classic batik designs; (3)relevance of philosophy values of classic batik with character education; (4) relevance of cultural and character values with the material to be learnt and (5) batik as nation identity.

This orientation activity also covers apperception activity which is reminding the material that has been learnt by students with the material to be taught. As explained by Bruner that memory is a process where study information is kept and able to be re-read or refreshed.

\section{Exploration Stage}

It is a combination of teacher activities in delivering information and organizing students in study group with students activities in selecting and sorting values through group discussion. Teacher delivers information concerning material in accordance with the study objective related to the orientation and apperception activities.

In group, students will initiate to track various study sources and text book to identify, analyze the issues and problems becoming group assignment, describe values in the context of events/issues to be studied. Based on group discussion, students sort and select values, and describe action examples relevant to values selection. It is a thinking process involving mental operation in form of classification, induction, deduction and logical thinking. Sorting and selecting activity is relevant to study theory of Bruner namely "discovery". The princple is thinking process covers creation of definition, creation of opinion and conclusion drawing. Study and learning will be meaningdul in the event that students succeed relating information with the relevant concepts in the cognitive structure during the learning. 


\section{Elaboration Stage}

Teacher facilitates students in order to make discussion runs well and create new idea verbally and in written. Disscussion provides opportunity to think and analyze in order to solve any issue and act without fear in discussion. Facilitating students in cooperative and colaborative learning and competing in healthy way in order to improve study achievement and faciltating students to present the group work result.

Students appreciate the value selection and express the value selection in group disscussion and class disscussion. Students disscuss cooperatively and collaboratively in each group. Based on class discussion, students express and confirm the value selection relevant to the issue. Students actively collaborate with the group in performing (1) analytic thinking process the ability to seperate material to the necessary parts, find relation between parts, able to see how the components connected and organized and therefore they are able to finish the questions; (2) synthentic is ability in connected and related elements and preparing it to be new roundness similar to pattern and knowledge structure (3) The last aspect is evaluation which is an aspect including previous aspects and therefore they are able to confirm value selection and express it with examples.

Study is an active process to develop scheme and therefore the related knowledge tends to be spider web. Elaboration stage of "IBNBBK" model related to the cognitive development is influenced by three basic processes: assimilation, accomodation, and equilibration. Based on such process, students are expected to achieve "IBNBBK" learning model development objectives which are knowledge improvement, students character and behavior development to batik as nation identity

This activity develops affective aspects after initiated by high level thinking activity including aspects of organizing, generating, investigating and evaluting and therefore students are able to sort and select values. Therefore, this activity will provide the students "ethos", "values", "faith", "needs" to live together with other people or other groups.

\section{Confirmation Stage}

Teacher and students justify the misunderstanding, provides strenghtening and conclusion of disscussion result. Students clarify disscussion result which is not understood yet in order to evaluate and test the relevancy of values selected with the action examples in school and community. Students under teacher guidance perform reflection and conclude disscussion result, declare the position and reason, test with various situation and actualize it in their lives in school, community, or country. 
Knowledge is not obtained passively but on the basis of action. This stage is relevant to values education objectives which are (1) assisting students to have consciousness and identifying values of their own and other people.(2)assisting students in order to be able to communicate openly and honestly with other people, (3) assisting students to be able to use rational behavior ability and their own behavior collectively. Therefore, IBNBBK learning model emphasizes more to how students study not how teacher teaches. Teacher responsibility in learning is stimulating and motivating students, diagnosing and handling any difficulties faced by students as well as providing experience to grow and building students knowledge. Cognitive development of students depends on how active the student in manipulating and interacting with their environment.

\section{Closing stage}

Teacher and students together concludes the entire study experiences that have been performed, identify positive and negative feelings that occur, determine final recommendation for each value, and actualize personal behavior of each students continously and therefore value internalization process occurs. The important step in this activity is (1) character strengthening developed by students in exploration and elaboration stages. (2) structurized assignments as the follow up and continuation of value clarification learning model development and therefore students have morale knowledge which is useful for moral judgement and moral reasoning that will influence their behavior.

The last stage of IBNBBK learning model developed is relevant to learning thinking explained by ki Hadjar Dewantoro's tut wuri handayani. In the process of packing the knowledge up between one student and another student, different argument or even mistake occurs. At this point, teacher should provide assistance and guidance (scafolding) as facilitator and counselor. It is called as constructivism in learning which is the proactive and reactive activity of students in building and developing knowledge and therefore complete constructivism is achieved (powerfull constructivism).

\section{b. Social System}

Social system is the role of teacher and student as well as type of rules required in IBNBBK learning that is opened to students or groups opinion. Teacher (1) has creative action to develop group activity; (2) provides freedom for students in expressing opinion.; (3) supports students or groups in finding values; (4) supports students or groups in relating values with daily life; (5) responsible for the ideas coming from group; (6) supports students or groups to actualize in action; (7) provides opportunity for students to reflect and confirm value selection in form of relevant behavior 


\section{c. Reaction Principles}

Based on general definition of reaction principle, teacher roles in IBNBBK learning model for the purpose of nation identity strengthening as facilitator are, (1) delivering learning objectives clearly;(2) presenting early information concerning values/values source (classic batik).(3) directing and organizing students to construct values ; (5) providing freedom for students in delivering opinion in group/class discussion; (6) guiding groups to work and study.; (7) supporting students/groups in finding study sources ; (8) evaluating process and study result; (9) provides study sources,

\section{d. Supporting System}

This IBNBBK requires supporting system which are:

1) RPP of IBNBBK model

2) Cards containing batik pictures and philosphy meaning,

3) Students worksheet in group method

4) Evaluation sheet, in order to measure students competency mastery .

5) Observation sheet in order to evaluate learning and teaching activity process.

6) Behavior scale test

\section{e. Instructional and Supporting Impacts}

Instructional impact :

1) Students identity strengthening

2) Students competency mastery

Supporting Impact

1) Study independence

2) Study Activeness.

3) Tolerance and responsibility

4) Positive behavior/interested in social studies

\section{Testing Result of IBNBBK Model}

Based on limited testing for three times in Public Junior High School 19 and widely testing in three schools groups (Public Junior High School A, Public Junior High School B and Private Junior High School), value increase to knowledge components occur considered from completion percentage, and therefore Public Junior High School (A) is higher while students character and behavior component to batik as nation identity in private junior high school shows higher number than public junior high school (R).

This finding shows that school culture can have significant influence to the knowledge achievement and creation as well as establishment of students behavior 
to batik as nation identity. In relation to the finding, it can be explained that the success of IBNBBK learning model implementation is also influenced by school condition including students, teacher, facilities and school culture. Generally, public school emphasizes more to knowledge development. This indicator can be explained based on the entrance standard of Public Junior High School which is based on National Final Examination score. Based on IBNBBK learning model implementation, it is proven that the percentage of learning completion achievement in public school groups for knowledge component is higher that private school.

'Based on model implementation result test, within character and nation component, the percentage of learning completion achievement in private school is higher. This finding can be explained based on school culture developed. Randomly, private school used as model testing is religious-based school. This school has religious education culture within the entire learning and teaching process in school which has significant influence to character education and behavior establishment of students. The main intrinsic mission in every religion is peace, harmony and safety spirit. This concept, according to Amin Abdullah (2007), contains meaning that education is not only introducing religion teaching to the students but also teaching humanity vision appreciation of the religion (teaching about religion and teaching about being religious).

Mision of peace message (religion) is not provided in form of doctrinization but inquiry of value and at the same time, basic values are implanted becoming character education core values reflected: integrity, modesty, faithfulness, courage to do the right thing, justice, patience, discipline, simplicity, politeness and obedience (consistency). Based on the values of inquiry process, students will find morale values within learning context, at the same time school creates conducive environment for implanting basic values to core values of character education. This school culture will be internalized in students personality and at the end, it will influence students personality and therefore they become human with good and strong character. Character education is started by knowledge (theory) that can be sourced from religion, social, cultural knowledge, in this context it comes from classic batik cultural values Such knowledge is expected to be able to form noble behavior and morale supporting students to apply the knowledge. Therefore, noble values internalization process will occur continously in the context of social environment.

Implications of testing implementation finding of IBNBBK learning model are : (1) culture values integration from students environment in social studies learning will improve the mastery of students knowledge to learning material. (2) The success of IBNBBK learning in character strenghthening and students behavior to batik as nation identity requires to be accompanied by school culture development implanting basic values to core values of character education (3) School as gathering place for students from various groups, race, culture and gender is expected to be able to transform religion noble values considered as 
"absolute" and relative cultural value to "core values" of character education emitting from altruistic values within diversity.

The impact of implication is the growth and development of other fundamental values such as sympathy, loyalty, tolerance to various differences and mutual trust between groups based on religion, ethnic, race, and tribe. This condition is voiced by Postmodernism movement.

\section{Effectinevess of IBNBBK Model}

Validation test is implemented in order to see the effevtiveness of IBNBBK model to the improvement of students knowledgeto learning material, character strenghtening and students behavior to batik as nation identity.

\section{a. Improving Students Knowledge}

Validation test result shows and presents some differences of experiment group compared than control groyp, this indication can be known from : (1) average score of knowledge pre-test between experiment group and control group has no significant difference, it shows that the first ability before the test between experiment group and control group is almost similar; (2) average score of knowledge pre-test in experiment group is higher than post test score average, (3) the average score of knowledge post test of the member in experiment group is higher than the average score of knowledge pos test of the member of control group, (4) there is a significant differences between average score of knowledge post test in experiment group based on school level category (Public Junior High School A, Public Junior High School B and Private Junior High School), (5) the average score of knowledge pre test between experiment group and control group has no significant difference, it shows that the first ability before the test between experiment group and control group is almost similar

Based on the evaluation result of validation test, it can be concluded that IBNBBK model has high effectiveness in order to improve the knowledge of students to social studies material. Model implementation to experiment group has positive influence to the improvement of students knowledge of social studies material, it shows from the average score of pre test and post test which has significant difference. Another effectiveness of IBNBBK learning model is the significant difference between average score of post test of the member of experiment group with control group. It provides indication that social studies learning using IBNBBK learning model has been able to improve students knowledge.

Validation test also provides description that the average score of post test knowledge based on school groups has differences but the differences remains to place the score of Public Junior High School (A) is above average. It means that "IBNBBK" learning model used in social studies learning has been able to 
improve students knowledge to the better direction (above the general average score).

\section{b. Students Character Strengthening}

Validation testing result shows the differences of the average score of character of experiment group compared with control group, this indication is able to be known based on : (1) the average score of character pre test in experiment group is higher than the average score of post test, (2) the average score of caharcter post test in experiment group is higher than the average score of post test in control group, (3) there is a significant differences between the average score of character post test in experiment group based on schooll level category (Public Junior High School (A), Public Junior High School (B) and Private Junior High School (S)),

Based on the result of validation test, it can be concluded that IBNBBK model has high and significant effectiveness to improve students character. There is a significant differences of the average score of post test in experiment group and control group. Model implementation in experiment group can have positive influence to the character improvement, it provides indication that social studies learning using IBNBBK model has been able to improve students character

Validation test also provides illustration and description that IBNBBK model is able to improve the average score of character post test in any and all school groups (Public Junior High School A, Public Junior High School B and Private Junior High School). Therefore, implementation of "IBNBBK" learning model is able to strengthen students character in all school category.

This finding shows and presents that implementation of "INBBK" model has contribution to students character strengthening. This result shows that education has centripetal power in the establishment of behavior, way of life, way of thinking within the community. Education is the most strategic facilitues in preserving values system developed in life. Based on this "values inquiry" process, students personality remains to be maintained in the middle of the more complex values meaning shift. It will improve "cultural added values" reflected in dignity, pride, nation character and identity.

\section{c. Students behavior to Batik as Nation Identity.}

Validation testing result shows and presents that the differences of average score of students behavior to batik as nation identity in experiment group compared with control group, this indication can be known based on : (1) the average score of pre test for the students behavior to batik as nation identity in experiment group which is higher than the average score of post test, (2) the average score of post test in experiment group is higher than the average score of post test in control group, (3) there is a significant difference between the average score of 
post test for the students behavior to batik as nation identity in experiment group based on school level category (Public Junior High School A, Public Junior High School B and Private Junior High School).

Implementation of model in experiment group has positive influence to the improvement of students behavior to batik as nation identity, it is showed from the result of average score of pre test and post test score which is significantly different. Based on the validation test, or it can be concluded that IBNBBK model has higher effetiveness to improve students behavior to batik as nation identity. The effectiveness of IBNBBK learning model is the significant difference of the average score of post test between experiment group with control group. It shows indication that social studies learning using IBNBBK model has been able to improve students behavior to batik as nation identity. Validation test also has given illustration that IBNBBK model is able to improve students behavior to batik as nation identity in any and all school groups (Public Junior High School A, Public Junior High School B and Private Junior High School).

This finding shows that cultural values integration and local wisdom coming from classic batik has influenced students behavior to batik as nation identity. Cultural values are very important especially related to the issues concerning 'a sense of identity' creating nation state consciuesness. The high signification values of identity sense concept attached in cultural concept as a result that contains certain values spirit believed to have 'similarity' characteristic in becoming social capital for the nation entity presence (Poespowardojo, 1986:30) .

Some findings show that IBNBBK model is effective in improving knowledge/competencymastery, nation character and identity strengthening. This result shows that digging and replanting classic batik cultural values, inherently based on education, contributes to build nation identity and functioned as filter in selecting other culture influence. "Local Wisdom" values affirm the strategic function for nation character and identity establishment.

Therefore, the excellences of social studies learning model based on Surakarta classic batik art cultural values are: 1) Learning process becomes interesting and meanigful for students. Students, with their own way, perform reconstruction of knowledge and values and behavior in learning process and implement them in their living reality and social environment; (2) based on "value inquiry" process, students personality remains to be maintained in the middle of the more complex values meaning shift (3) learning process will improve "cultural added values" which is able to improve dignity, pride, nation character and identity

\section{d. Impact of IBNBBK Model}

1).To build Confidence and Tolerance

Enthusiam and activeness of students in learning process is the positive implication that IBNBBK learning grows and builds courage and ability to deliver opinion to the students. In addition, it also grows and builds tolerance to the 
diversity and builds sympathy and empathy behavior without differentiating religion, race and gender. Educational process enclosing students to social discourse will support social sensitivity to human and exploitation phenomenon. At the end, social responsibility to others will grow, high tolerance to diversity and fair acceptance to race and group differences.

One of characteristics of "IBNBBK" learning model is student centered, the more involvement of students in learning activity, the more study activities performed by students. In "inquiry" process situation, students are not only learning the concepts and principles but students are also experiencing learning process concerning self direction, responsibility, social communication.

The improvement of students positive activities in "IBNBBK" learning model can eliminate impression that social studies subject is a boring and less interesting subject. Activities in "IBNBBK" learning model has shown that social studies subject becomes interesting and not boring. This condition is influenced by variation of stages in "IBNBBK" learning model that providies the widest opportunity to the students in finding values and realizing values in form of morale action related to the students and their social interaction.

\section{2). Teacher Performance}

Development of teacher teaching skills shows that during the testing of teacher skills and the teacher uses various teaching skills, it experiences progress. It is seen from the critical dialogue between teacher and student, and between student and student in order to obtain meaning similarity or relevancy of subject material within students cultural social environment context.

Teacher has performed evaluation during learning process and at the end of learning, and therefore there is a consciousness for teacher and student that learning process is as significant and important as study result. Therefore, teacher is not only developing students knowledge aspects but also students character and behavior.

Students activity improvement during learning can not be disconnected from teacher role as facilitator and provides strengthening to students in order to investigate various learning sources meaning that teacher guidance and direction make students to be active. IBNBBK learning activity is centered to students, students active involvement in group discussion and class discussion in values clarification process requires teacher guidance and direction.

Teacher ability in responding examples objectively shows that teacher has understood the position and role in "IBNBBK" model which is as guide and facilitator. Therefore, teacher assists the students to have ability in actualization of values selection to ethic dimension action. It will make students have social awareness and emphatic behavior to the people outside their social, culture and religion margin. Teacher ability to integrate local culture can build students interest and motivation to actively involve in social studies learning. It means that teacher has been suceeded to build curiousity interest of students to their regional cultural values. 
Learning media is the essential element in IBNBBL learning which are, in this case, classic batik designs. The testing has shown that teacher ability in preparing and using media is more developed. Teacher has also been able to place himself/herself as Role model as a VCT learning guidance. It means that teacher has realized that social studies learning based on classic batik cultural values can not be separated from media (batik) and therefore teacher requires to provide themselves with knowledge and cultural values knowledge developed from classic batik designs. It is seen from the beginning of learning, teacher has been succeeded in building the student interest by showing and presenting batik designs pictures and explaining the philosophy meaning and to make students actively involve in the learning.

Learning process emphasizies that "students individual" as study subject in conformity with character education and moral autonomy in neighborhood, community, nation and country. Character education is initiated by knowledge (sorting and selecting values). Knowledge (theory) can be sources from religious, social and culture knowledge. The knowledge is expected to be able to form the noble behavior or morale (expressing and appreciating values) and at the end implementing the knowledge. Education is not only building and developing the entire human aspects but also educational practice based on a series values as guidance between cognitive, affective, and psychomotor world.

\section{Conclusion and Recommendation}

Social studies learning condition at Junior High School in Surakarta, until now, less uses students environment as study source and only based on text book. Therefore, social studies is regarded as a boring subject for students and does not support and motivate students to have critical thinking and less develops sensitivity to their social environment. This condition has given impact to the occurence of stigma that social studies has less benefit for daily life and considered as not interesting subject. The objective of learning is not comprehensively developing cognitive, affective and psychomotoric aspect. Innovation of limited source and media development also causes the learning implementation is not moving from transfer of knowledge tradition. Likewise, based on the learning evaluation, it remains to prioritize evaluation result and mostly only develop cognitive aspects.

"IBNBBK" learning model design is entered into RPP in accordance with the provision regulated in the regulation of Ministry of National Education No. 41 year 2007> regarding Standard Process for Primary and High Education Unit. The formulation of "IBNBBK" objectives includes three objective aspects: (1) knowledge mastery aspect, related to material,(2) behavior development including the activities of selecting and appreciating values and performing actions in accordance with the values selected; (3) social skills development and its relevancy with the morale values selection found in social studies material context. 
Learning implementation procedure or steps (syntax) of 〈IBNBBK〉 learning model consists of three stages which are: (1) Apperception and Orientation (stage I, Cooperation) (2) Exploration (Stage 2, 3 Cooperation and phase of VCT values sort and selection) (3) Elaboration (Stage 4-5 Cooperative and Phase of appreciating and expressing VCT values selection) (4) Confirmation (Phase 6 and Phase of VCT Value Internalization), (5) closing.

Of the five stages, stage 1 Apperception and Orientation focus on teacher activities. Stage two to five is more dominant to students activities in group which are performing VCT process by three activities stages which are : (1) emphasizing rational ability; (2)reflecting effective dimension (appreciation and pride); (3) reflecting psychomotoric dimension (continous and patterned concrete action). In the stage two to five, teacher roles are as : (1) facilitator and therefore students are collaboratively able to study and cooperate with their groups; (2) creating conducive study condition and therefore students are able to perform model stages; (3) source able to provide strengthen and motivate students to use various study sources; (4) motivator in character values strengthening

"IBNBBK" learning model is oriented not only for the purpose of students success in mastering material but also developing rational thinking ability, developing effective dimension (appreciation and pride to values selection), developing psychomotoric dimension (concrete action which is continous and the relevancy is patterned with values selection). Therefore, evaluation in "IBNBBK" learning model includes learning process evaluation and learning result evaluation. Process evaluation is aimed to have knowledge concerning student actiuvity in group and individual activity. Study result evaluation is aimed to measure the aspects of knowledge, rational thinking ability, appreciation and pride to values selection and ability in performing morale action related to the values selection continously. In addition, evaluation to group and individual portfolio is also able to be implemented based on students work result as entered into Students Work Sheets.

The success of model is to improve the mastery of knowledge, nation character and identity. Limited testing analysis result by expert validation test and implementation in the field shows valid model to be used in wide testing. The implementation of model testing stage 2 or wide testing refers to Class Action research. Model development testing by class action research in three school groups which are Public Junior High School A, Public Junior High School B and Private Junior High School in Surakarta the result has proved that the model is able to improve knowlegde, nation character and identity showing by the increase of the score of nation character and identity of $80 \%$. The increase of social studies knowledge (cognitive) is shown by at least $75 \%$ of second grade semester two students (research object) obtaining score 70 as the limit of social studies subject completion.

Therefore, the implementation of IBNBBK learning model in Public Junior High School group (A) and Public Junior High School group B and Private Junior 
High School has been performed in accordance with the model developed and able to improve the score of nation character and score of nation identity of $80 \%$. Model is also able to improve the study completion at least 75\%. "IBNBBK" learning model developed has met validity, practicality and effectiveness criteria.

Theoretical implication of this research result can be formulated as follows: First, pradigm change in social studies subject is necessary to be implemented not only as transfer of knowledge which is used until now. Teacher should change the learning tradition from resultoriented to critical thinking process andvaluesfinding process in learning material oriented. Second, the developed "IBNBBK" learning model must be able to meet the complete social studies learning characteristic and therefore in the formulation of learning objective, the rational thinking ability, effective dimension and psychomotoric dimension should be developed. Third, 'IBNBBK' learning model implementation procedure is designed by the steps of prioritizing students activities and therefore teacher consciousness to be a guide not material giver that is required. Fourth, implication of evaluation procedure in 'IBNBBK' learning model requires teacher to develop evaluation instrument by considering aspects of students knowledge, values and behavior as well as skills in actualizing learning values in school by self and their social environment context. Fifth, "IBNBBK" learning model is proven to have influence to the increase of knowledge, nation character and identity strengtening. Therefore, social studies learning in Junior High School requires to adopt "IBNBBK" learning model.

Theoretically, this research results have the following implications: First, cultural meaning can be changed in accordance with the community thought. The creation reality which is "Classic Batik " as Indonesian nation identity coming from local culture is the implementation of narrative tranfer "from grand narative to local narative'. Second, classic batik symbol containing "guidance and arrangement", the use contains "authority relation" is "deconstructed" for the purpose of character education. Third, educational process in postmodernism paradigm must be functioned to assist students in realizing that in life reality, there are many ways of constructing world (ways of world-making). Therefore, educational process must facilitate students to develop critical thinking in facing all problems and finding perspective and problematic meaning. Fourth, the implementation of IBNBBK learning model motivates students to be active in perfoming values finding process (value inquiry). Inquiry is not asking but finding the deeper meaning by intellectual activities and therefore they can more appreciate the subject learnt. Fifth, generally, IBNBBK learning model is expected to be one of solutions to meet social studies learning demand which is educating students to be a good citizen and supporting the achievement of learning objective in accordance with Competency Standard and Basic Competency.

There are some recommendations to be delivered by researcher which are: First, Integration of cultural values in social studies learning is proven to be able to build students participation in learning, and therefore teacher facilitates students to be able to describe the values to be modeled from social studies learning 
material. Therefore, learning becomes meaningful for students life. Second, IBNBBK learning model is the learning centered to the students and therefore teacher must be able to control themselves not to dominate the learning. Teacher position as facilitator and guide in order to make learning process runs well. Third, 'IBNBBK' learning model realizes social studies education characteristic and also functioned as values education useful for nation caharcter development. Fifth, IBNBBK model developmed based on $4 \mathrm{R}$ elements which are Richnes, Ricurssion, Relation and Rigor, and is succeded to improve the social studies competency mastery and students identity strengtening and therefore teacher understands and implements $4 \mathrm{R}$ elements in developing social studies learning and also as the effort to create and establish the powerful and meaningful social studies learning.

\section{REFERENCES}

Aldrich , B. A et al. (2009). "Teaching Approach ,Perceived Parental Involvement and Autonomy as Predictors of Achievement" in The International Journal of Research and Review,Vol.1.

Adimihardja, K. (2008). Dinamika Budaya Lokal. Bandung: Pusat Kajian Albany: State University of New York Press.

Alwasilah, A. C, dkk. (2009). Etnopedagogi Landasan Praktek Pendidikan dan Pendidikan Guru. Bandung: Kiblat.

Appadurai, A. (1996). Modernity at large: Cultural dimensions of globalization. Minneapolis: University of Minnesota Press

Borg, W. R. \& Gall, M.D. 1989. Educational Research. London: Longman Group.

Bruner, J. S. (1986). Actual minds, possible worlds. Cambridge, MA: Harvard University Press.

Cary, L. J. (2006). Curriculum Spaces: A Postmodern Approach to Educational Research. Mahwah, NJ: Peter Lang.

Cherryholmes, H. (1988). Power and Criticism: Poststructural Invesitgations in Education. New York: Teachers College

Creswell, J. W. (1994). Qualitiative \& Quantitative Approach. London New Delhi:SAGE Publications.

Creswell, J.W. (1998). Qualitative Inquiry and Research Design: Choosing Among Five Derrida, Jacques .2001. Writing and Difference, Translated, with an introduction and additional notes, by Alan Bass. London: Routledge,

Crocco, M. S. (2006). Gender and sexuality in the social studies. In L. Levstik \& David E. Bloom, 2004 Globalization and Education: An Economic Perspective. In Globalization: Culture and Education in the New Millennium (edited) by Suárez-Orozco and Desirée Baolian Qin-Hilliard, California: University of California Press Berkeley and Los Angeles, California 
Derrida, J. (2001). Writing and Difference, Translated, with an introduction and additional notes, by Alan Bass. London :Routledge,

Dewantara, K.H. (1977). Karya Ki Hajar Dewantara. Bagian Pertama: Pendidikan.Yogjakarta: Penerbitan Taman Siswa.

Dewey, J. (1978). The Child and the Curriculum . Chicago: The University of Chicago Press. Chicago: The University of Chicago Press.

Doll, W. E. (1993). A Post-modern Perspective on Curriculum. New York: Teachers College Press.

Doyle, T. (2008). “The Learner-Centered Classroom.” Earner Centered Teaching. wordpress.com/articles-and-books/the-learner-centered-classroom/

E. Wayne, R . (2006). Curriculum Purposes, Problems, and Possibilities. USA: State University of New York for social change. New York: Falmer.

Farisi, M. I. (2006). Merekonstruksi Pembelajaran IPS Sekolah Dasar berdasarkan teori konstruktivis (Disertasi). Bandung: Program Pascasarjana UPI Bandung.

Gardner, H. (2004). How Education Changes: Considerations of History, Science, and Values,"( Edited ) Marcelo M. Suárez-Orozco and Desirée Baolian Qin-Hilliar. Berkelyy Los Angeles London: University of California

Giroux, H. (1992). Border Crossing: Cultural Workers and the Politics of Education. London: Routledge. Routledge.

Greda, W. R. (2002) Greda Wever Rabehl Global Citizenship and Global Solidarity through Study Abroad: An Exploratory Case Study of South Korean Students Sohyun An Kennesaw State University Journal of International Social Studies http://www.iajiss.org

Hasan, S.H. (1996). Pendidikan Ilmu Sosial. Jakarta: Proyek Pendidikan Tenaga Akademik.

Hasan, S.H. (2007). Makalah seminar Nasional Revitalisasi pendidikan IPS tanggal 21 Nopember 2007. UPI Bumi Siliwangi. Hasan

Hicks, D., Tlou, J., Lee, J., Parry, L., \& Doolittle, P. 2002. Global connections: Using the Internet to support citizenship education. International Journal of Social Education, 17(1), Somantri, Nu'man. (2001). Menggagas Pembaharuan Pendidikan IPS. Bandung: Remaja Rosdakarya.93-102\

Hok-chun, D. (2002). Quality Education through a Post-modern Curriculum Hong Kong Teacher's Centre Journal, Vol. 1, Spring 2002(C) Hong Kong Teacher's Centre 2002

Hursh, D. W., \& Ross, E. W. (Eds.). (2000). Democratic social education: Social studies

Irwan Abdullah. (2009). Kontruksi dan Reproduksi Kebudayaan. Pustaka Pelajar: Yogyakarta.

Jarvis, P.(1990). International Dictionary of Adult and Continuing Education. London : Routledge.

Jencks, C .(1986). What Is Post-modernism? New York: St. Martin's. 
Jenkins, H. (2004). Pop Cosmopolitanism: Mapping Cultural Flows in anAge of Media Henry Convergence."( Edited ) Marcelo M. Suárez-Orozco and Desirée Baolian Qin-Hilliar. Berkelyy Los Angeles London: University of California

Kalinggo, H. (2002). Batik sebagai Busana dalam Tatanan dan Tuntunan. Surakarta: Yayasan Peduli Kraton Surakarta Hadiningrat.

Kumar, A. (2009). Social studies in the postmodern world: An essay review. Education Review, 12v(10). Retrieved [date] from http://edrev.asu.edu/ essays/v12n10index.html

Lasmawan, (2009). Pengembangan model Integrasi Domain Sosial Dan Budaya dalam pembelajaran IPS SD (Studi Pengembangan Model Pengorganisasian Materi IPS - SD Berbasis Sosial - Budaya) (Laporan Penelitian). Singaraja: Lembaga Penelitian IKIP Negeri Singaraja

Marcelo, M. (2004). In Globalization: Culture and Education in the New Millennium in.(edited) Suárez-Orozco and Desirée Baolian Qin-Hilliard, California: University of California Press Berkeley and Los Angeles, California

Mc Millan, H, J. \& Schumacher, S. (2001). Research in Education. New York: Longman.

McLuhan, M. 1962. The Gutenberg Galaxy: The Making of Typographic Man. Toronto: University of Toronto Press

Muhadjir, N. (2000). Metodologi Penelitian Kualitatif Edisi IV. Yogyakarta:Rake Sarasin

Muhadjir, N. (1982). Teori Perubahan Sosial. Yogyakarta: Rake Sarasin

Muhaimin. (2004). Paradigma Pendidikan Islam; Upaya Mengefektifkan Pendidikan Agama Islam di Sekolah. Bandung: PT. Remaja Rosdakarya.

National Council for the Social Studies. (1994). Expectations for excellence: Curriculum standards for social studies. Washington, D.C.: National Council for Social Studies.

Nieto, S (2004). Language, Culture and Teaching . Chicago: National Reading Conference

Noffke, S. E. (2000). "Identity, community and democracy in the new social order." In D. W. Hursh \& E. W. Ross (Eds.), Democratic social education: Social studies for social change (pps. 73-83). New York: Falmer.

Robert C. Scharff and Val Dusek. (2003). Philosophy and Techonology. The Technological Condition. An Anthology. London: Blackwell.2003, 487-489.

Ross, E. W. (1997). The struggle for the social studies curriculum. In E. W. Ross (Ed.), The social studies curriculum: Purposes, problems, and possibilities (pp. 3-20). New York: State University of New York Press.

Schubert, W. H. (1991). Historical perspective on centralizing curriculum. In M. F. Klein (Ed.), The politics of curriculum decision-making (pp. 98-118).

Schug, M. C., Western, R. D., \& Enochs, L. G. (1997). Why do social studies teachers use textbooks? The answer may lay in economic theory. Social Education, 61(2), 97-101. 
Segall, Avner; Heilman, Elizabeth E. \& Cherryholmes, Cleo H. (Eds.) (2006) Social Studies-The Next Generation: Re-searching in the Postmodern. New York: Peter Lang Publishing. Inc.

Seri Penerbitan. "Indonesia Indah". (2000): Mengenai Latar Belakang Kehidupan Bangsa Indonesia Adat Istiadat dan Seni Budayanya. Jakarta: Yayasan Harapan Kita/BP 3 TMII

Sewan, S. (1980). Seni Kerajinan Batik Indonesia. Jogyakarta: Balai penelitian Batik dan KerajinanInc. Pp. vii + 299 ISBN 0-8204-7067-8

Slattery Patrick, Curriculum development in the postmodern era. Madison Avenue New York:Routledge Taylor \& Francis Group .

Stein, S. (2000). "Equipped for the Future Content Standards : What Adults Need to Know and Be Able To Do in the 21st Century." National Institute for Literacy.

Sumaatmadja, N. (2000). Manusia dalam Konteks Sosial Budaya dan Lingkungan Hidup. Bandung: Alfabeta.

Supriatna, N. (2006). Konstribusi Pembelajaran Sejarah yang berorientasi pada Masalah Sosial Kontemporer. Disertasi. Bandung: Program Pascasarjana UPI Bandung.

Thornton, S. J. (2004). Teaching Social Studies that Matter: Curriculum for Active Learning. New York: Teachers College Press. . 